\title{
Effect of Pore Structure of Cigarette Paper on the Yield of Carbon Monoxide in Mainstream Smoke During Cigarette Burning *
}

\author{
by \\ Luo Wei, Yin Donghong, Ding Duo, Chen Zeliang, Wang Pingjun, Zhong Kejun, and Ren Jianxin \\ Research and Development Center of China Tobacco Hunan Industrial Co., Ltd., Changsha, Hunan, China
}

\section{SUMMARY}

Two cigarette papers with the same basis weight and permeability but different pore structures were prepared. The effect of the pore structure after pyrolysis on $\mathrm{CO}$ yield in mainstream smoke was investigated by heating the papers to $250{ }^{\circ} \mathrm{C}$. Diffusivity, permeability, pore size distribution, and pore volume of the cigarette papers before and after heating were also measured. The pore structures of the completely pyrolyzed cigarette paper in the burning cone and the incompletely pyrolyzed area near the char line were elucidated. $\mathrm{CO}$ yield in mainstream and sidestream smoke and the temperature distribution of the burning cone were evaluated. Diffusivity and permeability of the cigarette papers after heating were significantly higher than of the control sample after heating. The volume of pores in the cigarette paper with a size of $0.1-8.0 \mu \mathrm{m}$ was increased, which decreased $\mathrm{CO}$ content in mainstream smoke. An increase in the amount of micropores facilitates $\mathrm{CO}$ diffusion from mainstream to sidestream smoke. [Beitr. Tabakforsch. Int. 26 (2015) 284-293]

KEY WORDS: Cigarette paper, carbon monoxide, pore structure, mainstream smoke, diffusion.

\section{ZUSAMMENFASSUNG}

Es wurden zwei Zigarettenpapiere mit gleichem Basisgewicht und Durchlässigkeit, aber unterschiedlicher Porenstruktur vorbereitet. Die Auswirkungen der Porenstruktur auf die CO-Ausbeute im Hauptstromrauch nach Pyrolyse wurden durch Erhitzung der Papiere auf $250^{\circ} \mathrm{C}$ untersucht. Diffusionsvermögen, Durchlässigkeit, Porengrößenverteilung und Porenvolumen der Zigarettenpapiere vor und nach der Erhitzung wurden ebenfalls bestimmt. Dabei wurde die Porenstruktur des vollständig pyrolysierten Zigarettenpapiers im Brennkegel und des unvollständig pyrolysierten Bereichs in der Nähe der Verkohlungslinie betrachtet. Die CO-Ausbeute im Haupt- und Nebenstromrauch und die Temperaturverteilung des Brennkegels wurden untersucht. Das Diffusionsvermögen und die Durchlässigkeit der Zigarettenpapiere nach der Erhitzung waren signifikant höher als bei der Kontrollprobe nach der Erhitzung. Das Volumen der Poren im Zigarettenpapier mit einer Größe von $0,1-8,0 \mu \mathrm{m}$ war vergrößert, wodurch der $\mathrm{CO}-$ Gehalt im Hauptstromrauch reduziert wurde. Eine höhere Anzahl von Mikroporen fördert die CO-Diffusion vom Haupt- in den Nebenstromrauch. [Beitr. Tabakforsch. Int. 26 (2015) 284-293] 


\section{RESUME}

Deux papiers à cigarettes furent préparés, qui présentaient la même masse surfacique et la même perméabilité mais se distinguaient par la structures de leurs pores. L'incidence de la structure des pores, après pyrolyse, sur le rendement de $\mathrm{CO}$ au niveau de la fumée principale fut analysée en soumettant ces papiers à des températures de $250^{\circ} \mathrm{C}$. La diffusivité, la perméabilité, la distribution de la taille des pores et le volume des pores de ces papiers à cigarettes furent également mesurés avant et après chauffage. Les structures des pores du papier à cigarettes totalement pyrolysé dans le cône de combustion et la zone partiellement pyrolysée à proximité de la ligne de carbonisation furent dégagées. Le rendement en CO de la fumée principale et de la fumée latérale ainsi que la distribution des températures du cône de combustion furent évalués. La diffusivité et la perméabilité des papiers à cigarettes observées après chauffage furent nettement plus élevées que celles de l'échantillon de référence après chauffage. Le volume des pores du papier à cigarettes d'une épaisseur de $0,1-8,0 \mu \mathrm{m}$ se trouva accrue, ce qui diminua la teneur en $\mathrm{CO}$ de la fumée principale. Une augmentation du nombre de micropores facilite la diffusion du CO de la fumée principale vers la fumée latérale. [Beitr. Tabakforsch. Int. 26 (2015) 284-293]

\section{INTRODUCTION}

Carbon monoxide is one of the harmful components in mainstream smoke and is also one of the most difficult to remove from cigarette smoke because of its distinct physicochemical properties. Many methods have been developed to reduce $\mathrm{CO}$ yield in mainstream smoke, including reduction of $\mathrm{CO}$ formation during cigarette burning and restriction of $\mathrm{CO}$ transfer to the mainstream smoke during puffing. Several approaches such as improving tobacco varieties, modifying the cigarette burning process and optimizing cigarette parameters (e.g., ventilation, diameter, length, tobacco weight) are commonly adopted by various manufacturers to produce a cigarette with a relatively low $\mathrm{CO}$ yield. In addition, dilution by filter ventilation is considered the simplest and most effective strategy to reduce cigarette "tar" and CO yield in mainstream smoke (1-3). In this way, air is introduced into the mainstream smoke to dilute $\mathrm{CO}$ during the cigarette puffing process. Also molecular sieves and porous materials have been investigated as filter adsorbents to reduce $\mathrm{CO}$ yield $(4,5)$. However, these materials are rarely employed in cigarette products because they possess low CO adsorption capacity. Furthermore, excessive dilution by filter ventilation and the use of porous materials in the filter as $\mathrm{CO}$ adsorbents often have a negative influence on the taste and cause tobacco smoke dryness. Catalytic oxidation of $\mathrm{CO}$ has been employed to remove CO (6-9). However, the addition of a catalyst into filter and tobacco shreds often poses some problems, such as high cost of the catalyst, catalyst deactivation, changes in taste, and difficulties in attaching the powder catalyst to the tobacco shreds.

Cigarette paper as a wrapping material, is relevant for the cigarette burning process and plays an important role in the generation of the $\mathrm{CO}$ yield. The influence of cigarette paper on $\mathrm{CO}$ yield has been reported. For example, GUO et al. (10) reported that $\mathrm{CO}$ yield in mainstream smoke can be decreased by increasing the amount of burning additives and the K/Na ratio. HAMPL (11) found that a decrease in fiber basis weight is favorable for reducing $\mathrm{CO}$ yield. FRITZSCHING (12) reported that use of a combination of calcium carbonates with different mean particle sizes as filler material in the cigarette paper significantly reduces $\mathrm{CO}$ yield. Such combination could also decrease $\mathrm{CO}$ content without altering air permeability of the cigarette paper. WALTZ and HÄUSERMANN (13) showed that the combined action of $\mathrm{CO}$ diffusion and air dilution could decrease $\mathrm{CO}$ content in mainstream smoke. MURAMATSU et al. (14) reported that the porosity of cigarette paper and the length of a cigarette can influence $\mathrm{CO}$ content by diffusion and dilution. ROSTAMI and HAJALIGOL (15) found that $\mathrm{CO}$ diffusion increases with increasing cigarette length, thickness of cigarette paper, and paper permeability. EITZINGER (16) reported that thermal decomposition of cigarette paper increases the pore volume without significant shift in pore diameters, this increases air permeability and diffusion constant, which helps to decrease $\mathrm{CO}$ content in mainstream smoke. However, the mechanism of the variation of $\mathrm{CO}$ diffusion due to the cigarette paper, particularly the effect of the pore structure of the cigarette paper on $\mathrm{CO}$ yield during the burning process, has not been reported.

The present work aims to investigate the in situ effect of the pore structure of the cigarette paper on $\mathrm{CO}$ yield in mainstream smoke. Two kinds of cigarette paper and a control sample with the same basis weight and permeability were designed and prepared. The pore structure of the cigarette paper was determined using a mercury porosimeter and a scanning electron microscope (SEM). The cause of the decrease of $\mathrm{CO}$ yield in mainstream smoke was also discussed. This study characterizes the pore structure of cigarette paper, and may help to design cigarettes with low levels of $\mathrm{CO}$ and other harmful components in their smoke.

\section{EXPERIMENTAL}

\section{Reagents and materials}

All chemicals were of analytical grade and used as received. Deionized water was used in all of the experiments. Nicotine ( $>97 \%$ purity) and heptadecane were purchased from Aldrich (Sigma-Aldrich, St. Louis, MO, USA. Isopropanol and anhydrous ethanol were obtained from local suppliers. The two designed cigarette papers (P2 and P3) and the control sample (P1) with the same basis weight and permeability were produced by Minfeng Special Paper Co., Ltd. (Jiaxing, China). The cigarette paper parameters are shown in Table 1.

Sample cigarettes (C2 and C3) were produced by using the designed cigarette papers (P2 and P3). For comparison, a control cigarette $(\mathrm{C} 1)$ was also prepared from paper sample $\mathrm{P} 1$. The parameters of the sample and control cigarettes including cigarette length, pressure drop, weight, firmness, and circumference were the same. Also the materials such as plugwrap and tipping paper, filter material and cut tobacco were identical. 
Table 1. Cigarette paper parameters.

\begin{tabular}{l|c|c|c|c|c}
\hline Sample & $\begin{array}{c}\text { Basis weight } \\
\left(\mathrm{g} \mathrm{m}^{-2}\right)\end{array}$ & $\begin{array}{c}\text { Permeability } \\
(\mathrm{CU})\end{array}$ & $\begin{array}{c}\text { Burn additive } \\
\text { K/Na citrate }\end{array}$ & $\begin{array}{c}\text { Filler } \\
\text { level } \\
(\%)\end{array}$ & $\begin{array}{c}\text { Filler } \\
\text { size } \\
(\mu \mathrm{m})\end{array}$ \\
\hline P1 & 28.8 & 61.3 & $2.12 \%$ & 28.8 & 2.0 \\
P2 & 29.1 & 61.8 & $2.08 \%$ & 32.0 & 3.0 \\
P3 & 28.9 & 61.2 & $2.06 \%$ & 32.1 & 4.5 \\
\hline
\end{tabular}

CU: air permeability

\section{Instrumentation}

The yield of $\mathrm{CO}$ in mainstream and sidestream smoke was tested using the Borgwaldt KC RM200A and Borgwaldt $\mathrm{KC} \mathrm{LM5}{ }^{+}$smoking machines (Borgwaldt $\mathrm{KC}$, Hamburg, Germany) (ISO puffing mode). Nicotine and water in mainstream smoke were measured using an Agilent 6890 gas chromatograph (Agilent Technologies, CA, USA). The diffusivity and permeability of the cigarette papers before and after heating were measured using a Sodim D95 paper diffusivity meter (Sodim, Paris, France) and a Sodim D23 paper permeability meter (Sodim, Paris, France). Thermogravimetry (TG) was conducted using a NETZSCH-STA-449C (Netzsch Gerätebau, Bavaria, Germany) instrument at a heating rate of $10^{\circ} \mathrm{C} \mathrm{min}-1$ in helium atmosphere. The cigarette paper sample with $\sim 10 \mathrm{mg}$ was put into an alumina crucible and heated from $30{ }^{\circ} \mathrm{C}$ to $900{ }^{\circ} \mathrm{C}$, and the flow rate was set at $40 \mathrm{~mL} \mathrm{~min}^{-1}$. The morphologies of the completely pyrolyzed cigarette paper in the burning cone and the incompletely pyrolyzed paper near the char line were observed using an EVO 18 SEM (Zeiss, Oberkochen, Germany) operated at an acceleration voltage of $10 \mathrm{kV}$. All of the test cigarettes were conditioned at $22 \pm 1{ }^{\circ} \mathrm{C}$ and a relative humidity of $60 \pm 3 \%$ for at least $48 \mathrm{~h}$ in a chamber (Lwl Development Ltd., Hong Kong). The pressure drop and weight of a cigarette were measured on a CNM-PFV203 pressure drop instrument (Institute of electronic engeneering, Changsha, China) and a CP 224S electronic balance (Sartorius, Göttingen, Germany), respectively. Prior to smoking, the selected cigarettes were within the range of $\pm 10 \mathrm{mg}$ from the average weight and $\pm 50 \mathrm{~Pa}$ from the average pressure drop. Conditioned cigarettes were smoked according to ISO puffing mode using a Borgwaldt KC RM200A (Borgwaldt $\mathrm{KC}$, Hamburg, Germany) smoking machine. The yields of "tar", nicotine, $\mathrm{H}_{2} \mathrm{O}$, and $\mathrm{CO}$ in cigarette mainstream smoke were determined in accordance with the national standards GB/T 19609-2004, GB/T23355-2009, GB/T23203.1-2008, and GB/T23356-2009, respectively $(6,10)$.

\section{METHODS}

\section{Heating the cigarette paper}

The designed cigarette papers (P2 and $\mathrm{P} 3)$ and the control sample (P1) with a size of $40.0 \mathrm{~cm} \times 26.5 \mathrm{~mm}$ were heated in an oven at four temperatures $\left(200,225,250,275^{\circ} \mathrm{C}\right)$ and four heating times $(10,15,20,25 \mathrm{~min})$, and then cooled to room temperature outside the oven. The heated cigarette papers were then stored in a sealed bag prior to measurement.

\section{Determination of diffusivity of the cigarette paper}

The diffusivity of a cigarette paper before and after heating was measured using a paper diffusivity instrument (Sodim, Paris, France) with the use of $\mathrm{CO}_{2}$ as reference gas. Each cigarette paper was tested for 20 times; average values were then calculated.

\section{Determination of permeability of the cigarette paper}

The permeability of the cigarette paper before and after heating was measured using the national standard method of China (GB/T23227-2008; for materials used as cigarette papers, plug wrap and tipping paper, including materials having an oriented permeable zone; determination of air permeability).

Characterization of pore structure of the cigarette paper using a mercury porosimeter

The pore structure of the cigarette paper before and after heating was determined using a Poremaster 60-GT mercury injection apparatus (Quantachrome, FL, USA). In a typical procedure, the cigarette paper is placed into the sample chamber and sealed, and then the testing pressure is increased from 1.38 to $206841 \mathrm{kPa}$ during measurement. Finally, the pore volume and pore size distribution of the cigarette paper were obtained by calculation using the software installed in the mercury porosimeter.

\section{Characterization of pore structure of cigarette paper by} SEM

After the cigarette had burned, images of a completely pyrolyzed area of a cigarette paper in the burning cone and of an incompletely pyrolyzed area near the char line were obtained using an EVO 18 SEM (Zeiss, Oberkochen, Germany). In order to determine the total pore number $(n)$, ImagePro Plus 6.0 was used to segment the SEM image into binary images first, and then a software was programmed by us to detect the pore one by one and the area calculated meanwhile by computer. The total pore area $(A)$, the mean pore area $(\bar{A})$, porosity $\left(\rho_{\mathrm{i}}\right)$, and equivalent pore diameter (D) of the combusted cigarette paper were calculated by the following equations:

$$
A=\operatorname{SUM}\left(A_{i}, \mathrm{i}=1,2, \ldots, \mathrm{n}\right)
$$

where $A_{i}$ is the pore area of the $\mathrm{i}$-th pore $(\mathrm{i}=1,2, \ldots, \mathrm{n})$

$$
\begin{gathered}
\bar{A}=(1 / \mathrm{n}) \times \operatorname{SUM}\left(A_{i}, \mathrm{i}=1,2, \ldots, \mathrm{n}\right) \\
\rho_{i}=A / A_{\text {measure }}
\end{gathered}
$$

where $A_{\text {measure. }}$ is the test area by SEM

$$
D=\sqrt{4 \times \frac{\bar{A}}{\pi}}
$$




\section{RESULTS AND DISCUSSION}

Mainstream smoke analysis of cigarettes wrapped with different cigarette papers

To determine the effect of the cigarette paper on $\mathrm{CO}$ yield in mainstream smoke, the cigarette papers P1, P2, and P3 were used to wrap the same brand of cigarette. The cigarette parameters yields of "tar", nicotine, and CO in mainstream smoke are summarized in Table 2 . The results indicated that the puff number of $\mathrm{C} 1, \mathrm{C} 2$, and $\mathrm{C} 3$ are almost the same. However, $\mathrm{CO}$ yield of $\mathrm{C} 2$ and $\mathrm{C} 3$ in mainstream smoke decreased by 1.33 and $1.40 \mathrm{mg} \mathrm{cig}^{-1}$ compared with that of $\mathrm{C} 1$.

\section{Selection of heating parameters}

The TG curves obtained from the pyrolysis process of cigarette paper samples are plotted in Figure 1(a). The pyrolysis process can be divided into three stages: (I) $\mathrm{H}_{2} \mathrm{O}$ evaporation; (II) cellulose pyrolysis; and (III) calcium carbonate decomposition $(17,18)$. The TG curves of P1, $\mathrm{P} 2$, and P3 showed almost the same pyrolysis behavior. Stage II corresponds to cellulose pyrolysis, which proceeds from $240{ }^{\circ} \mathrm{C}$ to $340{ }^{\circ} \mathrm{C}$ with $\sim 42 \%$ mass loss, as shown in the TG curves. Based on the thermolysis temperature of cellulose in cigarette paper, we selected the temperature range from $240{ }^{\circ} \mathrm{C}$ to $340^{\circ} \mathrm{C}$ as the heating temperature to simulate the incompletely pyrolyzed area of cigarette paper. Figure 1(b) shows the photograph of cigarette paper heated at different temperatures for $20 \mathrm{~min}$. When the cigarette paper was heated at $200{ }^{\circ} \mathrm{C}$, it becomes light yellow. At $225{ }^{\circ} \mathrm{C}$, it turns into a deep yellow color. At $250{ }^{\circ} \mathrm{C}$, the color changes into dark grey. In spite of the significant color change of cigarette paper at $250{ }^{\circ} \mathrm{C}$, it maintains a certain tensile strength and does not become brittle. However, a number of cracks appeared in the cigarette paper when it was heated at $275^{\circ} \mathrm{C}$. Beyond this temperature, the cigarette papers cannot be used for further measurement of diffusivity and permeability. The effects of heating temperature on the permeability and diffusivity of cigarette papers were also investigated (Figures 2(a) and 2(b)). The permeability and diffusivity increased with an increase in temperature. In addition, the pyrolysis of the cigarette paper is increased with an increase in temperature. Consequently, a temperature of $250{ }^{\circ} \mathrm{C}$ was adopted in the experiments.

The effects of heating time of the cigarette paper at a temperature of $250{ }^{\circ} \mathrm{C}$ on the permeability and diffusivity are shown in Figures 3(a) and 3(b). The results show that permeability and diffusivity increase with an extension of the heating time from $0 \mathrm{~min}$ to $20 \mathrm{~min}$, and then remained almost constant after $20 \mathrm{~min}$. Thus, a heating time of 20 min was selected in the experiments.

Table 2. CO yield in mainstream smoke.

\begin{tabular}{l|c|c|c|c|c|c|c|c}
\hline Sample & $\begin{array}{c}\text { Weight } \\
\left(\mathrm{mg} \mathrm{cig}^{-1}\right)\end{array}$ & $\begin{array}{c}\text { Pressure drop } \\
\left(\mathrm{Pa} \mathrm{cig}^{-1}\right)\end{array}$ & Puff number & $\begin{array}{c}\mathrm{TPM}^{\mathrm{a}} \\
\left(\mathrm{mg} \mathrm{cig}^{-1}\right)\end{array}$ & $\begin{array}{c}\mathrm{CO} \\
\left(\mathrm{mg} \mathrm{cig}^{-1}\right)\end{array}$ & $\begin{array}{c}\text { Nicotine } \\
\left(\mathrm{mg} \mathrm{cig}^{-1}\right)\end{array}$ & $\begin{array}{c}\mathrm{H}_{2} \mathrm{O} \\
\left(\mathrm{mg} \mathrm{cig}^{-1}\right)\end{array}$ & $\begin{array}{c}\text { "Tar" } \\
\left(\mathrm{mg} \mathrm{cig}^{-1}\right)\end{array}$ \\
\hline C1 & 900 & 1090 & 6.73 & 15.48 & 12.20 & 1.21 & 2.25 \\
C2 & 900 & 1090 & 6.76 & 14.83 & 10.87 & 1.18 & 12.02 \\
C3 & 900 & 1080 & 6.77 & 14.78 & 10.80 & 1.20 & 2.21 \\
\hline
\end{tabular}

a TPM: (Total particulate matter)
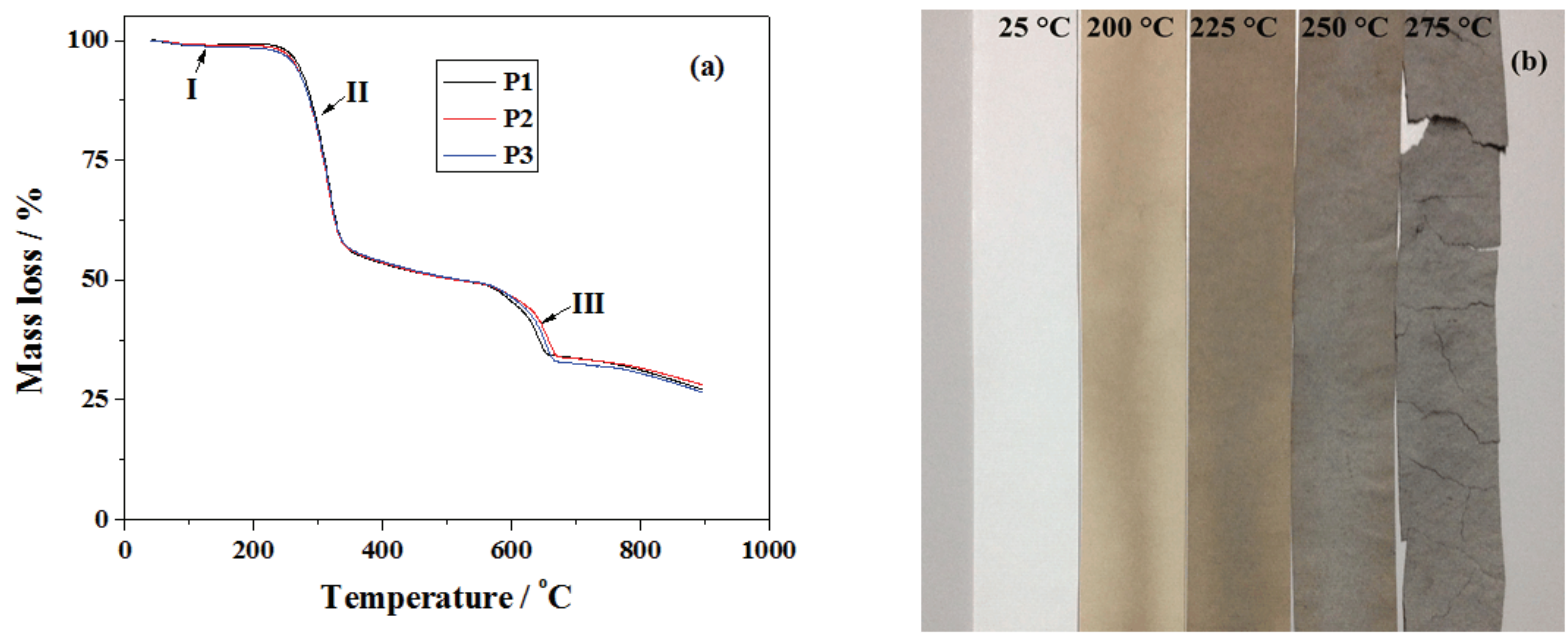

Figure 1. (a) TG curves of cigarette papers during pyrolysis, (b) and photographs of cigarette papers heated at different temperatures. 

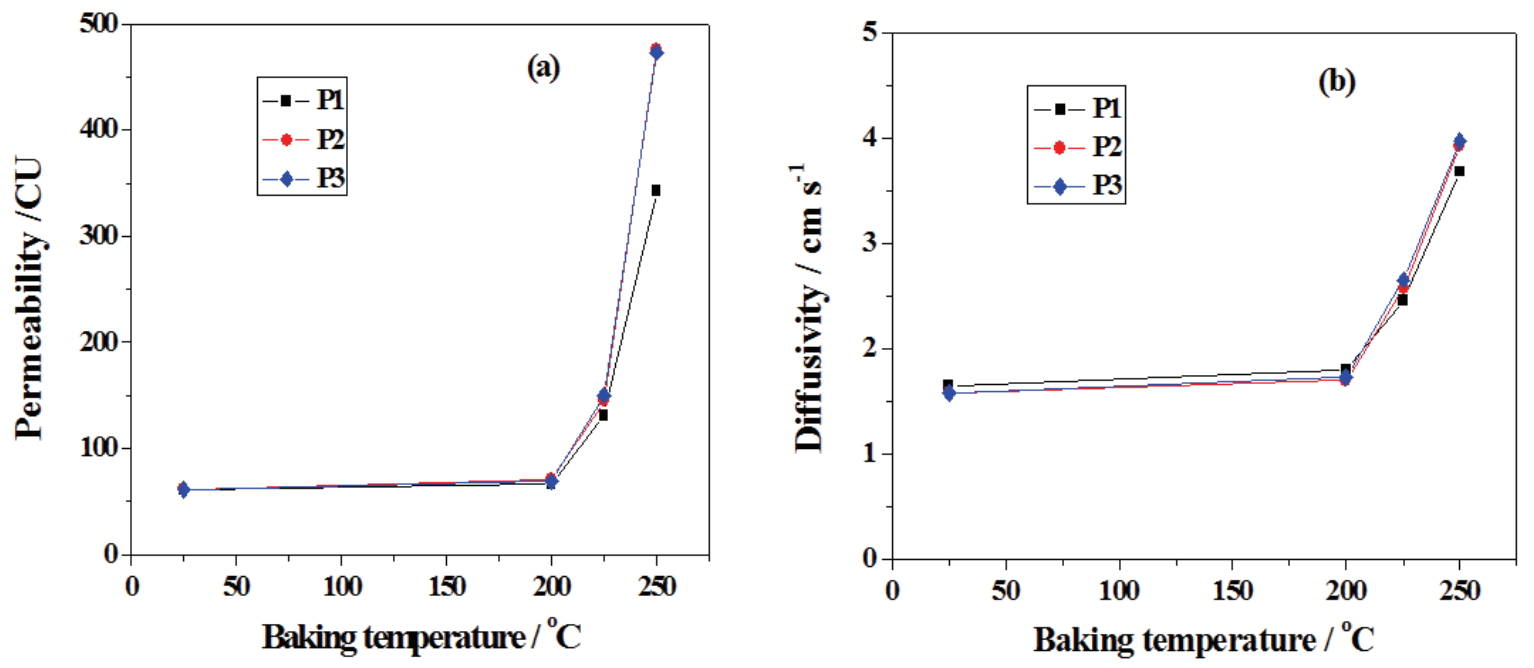

Figure 2. Effect of heating temperature on (a) permeability and (b) diffusivity of the cigarette papers.
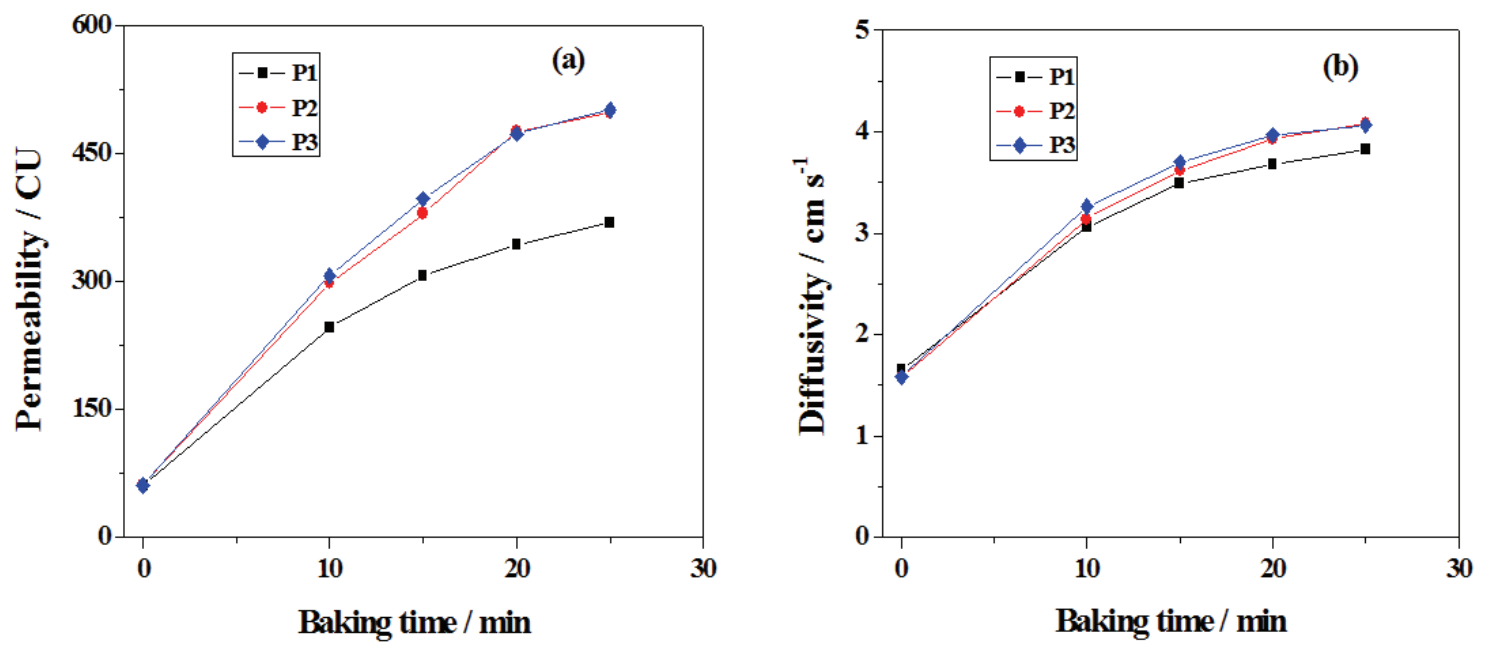

Figure 3. Effect of heating time on (a) permeability and (b) diffusivity of the cigarette papers.

Diffusivity and permeability of cigarette papers before and after heating

Accurate determination of the diffusivity and permeability of a cigarette paper near the char line is difficult because this area is too narrow. In this case, the cigarette papers were heated at $250{ }^{\circ} \mathrm{C}$ for $20 \mathrm{~min}$, to simulate an incompletely pyrolyzed area of a cigarette paper and to evaluate the change in pore structure. Diffusivity and permeability of the cigarette papers before and after heating were measured (Table 3 ). The results indicate that the diffusivity and permeability of P1, P2, and P3 after heating were increased from $459.5 \%$ to $672.8 \%$ and $123.0 \%$ to $151.2 \%$, respectively. Compared with the control sample of $\mathrm{P} 1$, the heated cigarette papers P2 and P3 showed significant increase in diffusivity and permeability, which may be due to the formation of micropores during the heating process. Obviously, the increased number of micropores of cigarette papers $\mathrm{P} 2$ and $\mathrm{P} 3$ enhance the diffusion of $\mathrm{CO}$, thereby reducing $\mathrm{CO}$ content in mainstream smoke.
Characterization of the cigarette paper pore structure by mercury porosimetry

It is difficult to distinguish the through-pores and dead-end pores of cigarette paper by using the existing characterization methods. Actually, the mercury porosimetry and SEM imaging methods do not only detect through-pores, but also dead-end pores. However, the original cigarette paper, especially the incompletely and completely pyrolyzed cigarette paper mainly possesses 3D matrix structures (through-pores) consisting of spindle calcium carbonate. Thus, we believe that the two methods are suitable for characterization of pore structure of cigarette paper. Figure 4 and Table 4 show that the pore sizes of the cigarette papers $\mathrm{P} 1, \mathrm{P} 2$, and $\mathrm{P} 3$ are in the range of $0.1-$ $200 \mu \mathrm{m}$. As shown in Figure 4, the heated cigarette paper (dash line) exhibits an increased pore volume compared with the pristine one (solid line). As shown in Table 4, the total pore volumes of $\mathrm{P} 1, \mathrm{P} 2$, and $\mathrm{P} 3$ after heating are increased 
Table 3. Diffusivity and permeability of the cigarette papers before and after heating.

\begin{tabular}{l|c|c|c|c|c|c}
\hline \multirow{2}{*}{ Sample } & \multicolumn{2}{|c|}{ Before heating } & \multicolumn{2}{c|}{ After heating } & \multicolumn{2}{c}{ Rate of increase (\%) } \\
\cline { 2 - 7 } & $\begin{array}{c}\text { Permeability } \\
(\mathrm{CU})\end{array}$ & $\begin{array}{c}\text { Diffusivity } \\
\left(\mathrm{cm} \mathrm{s}^{-1}\right)\end{array}$ & $\begin{array}{c}\text { Permeability } \\
(\mathrm{CU})\end{array}$ & $\begin{array}{c}\text { Diffusivity } \\
\left(\mathrm{cm} \mathrm{s}^{-1}\right)\end{array}$ & Permeability & Diffusivity \\
\hline P1 & 61.3 & 1.65 & 343 & 3.68 & 459.5 & 123.0 \\
P2 & 61.8 & 1.58 & 476 & 3.93 & 670.2 & 148.7 \\
P3 & 61.2 & 1.58 & 473 & 3.97 & 672.8 & 151.2 \\
\hline
\end{tabular}
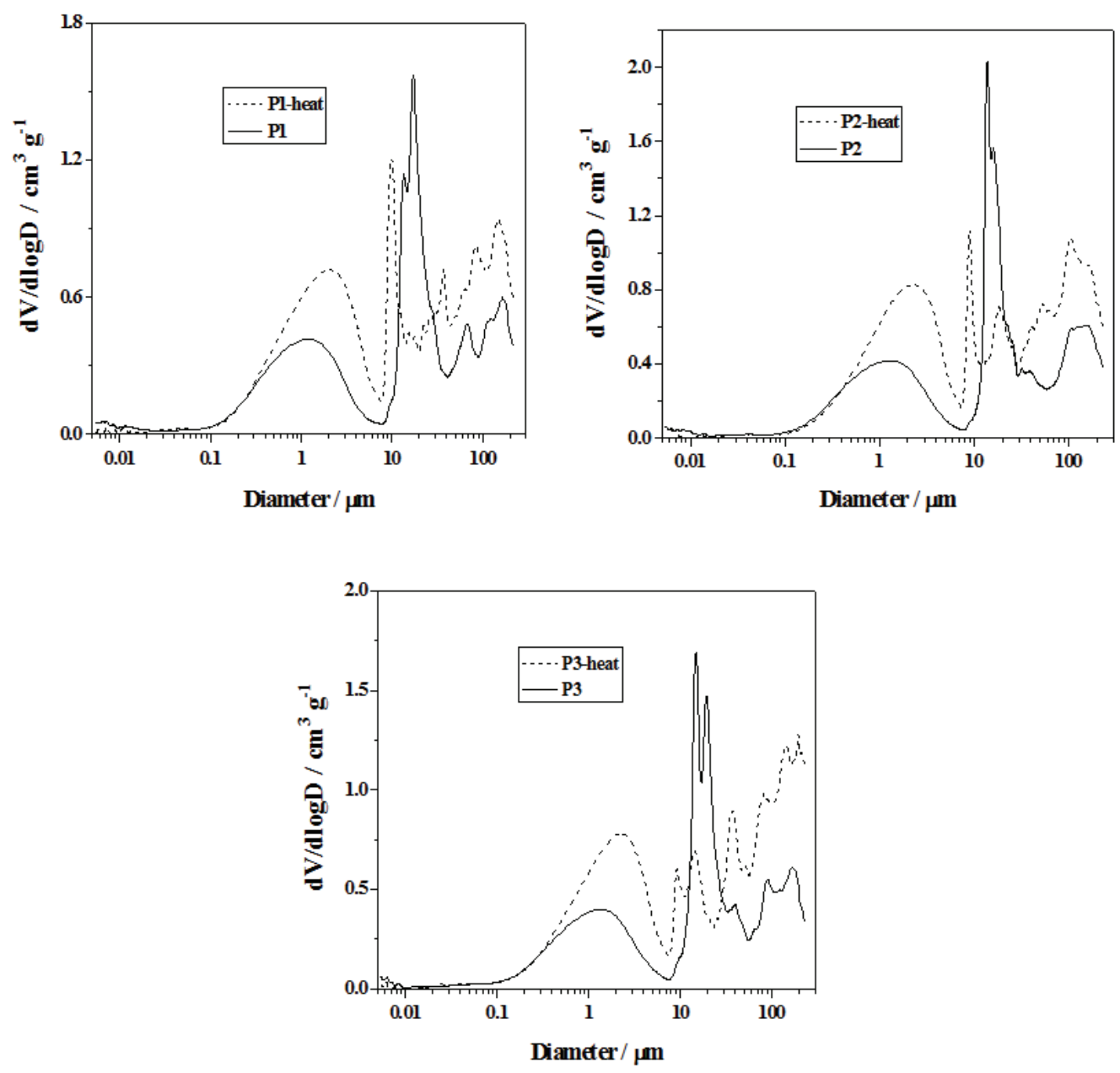

Figure 4. Pore size distribution $(0.01-200 \mu \mathrm{m})$ of the cigarette before and after heating.

from 1.674 to $1.857 \mathrm{~cm}^{3} \mathrm{~g}^{-1}$, and the $\mathrm{CO}$ contents in mainstream smoke are decreased from 12.20 to $10.80 \mathrm{mg}$ $\mathrm{cig}^{-1}$, respectively. The results indicate that the $\mathrm{CO}$ yield in mainstream smoke decreases as the in-total pore volume increases.

As shown in Table 4, the pore volumes of the heated samples of P1, P2, and P3 (pore size of 0.1-8.0 $\mu \mathrm{m}$ ) were increased by $60.3 \%, 74.1 \%$, and $81.0 \%$, respectively after heating. The pore volume has a negative correlation with the $\mathrm{CO}$ yield in mainstream smoke. However, the pore volumes of the heated samples P1, P2, and P3 in the pore size range of 8.0-50.0 $\mu \mathrm{m}$ decreased slightly $(\sim 10 \%)$, which suggests that no obvious correlation exists between the volume of pores with a size of 8.0-50.0 $\mu \mathrm{m}$ and CO yield in mainstream smoke. Furthermore, the pore volume of the heated samples P1, P2, and
$\mathrm{P} 3$, in the pore size range of $50.0-200 \mu \mathrm{m}$ increased by $64.6 \%, 74.1 \%$ and $106.4 \%$, respectively. The results indicate a negative correlation between $\mathrm{CO}$ yield in mainstream smoke and the volume of pores with a size range of $50.0-200 \mu \mathrm{m}$. The share of the pore volume in different pore size ranges, in the heated cigarette papers $\mathrm{P} 1, \mathrm{P} 2$, and P3 were respectively $45.2 \%, 45.4 \%$, and $42.1 \%$ for the pore size range of $0.1-8.0 \mu \mathrm{m} ; 26.2 \%, 24.4 \%$, and $23.2 \%$ for the pore size range of $8.0-50 \mu \mathrm{m}$; and $28.6 \%, 30.2 \%$ and $34.7 \%$ for the pore size range of $50-200 \mu \mathrm{m}$. Based on the porosimetry results and $\mathrm{CO}$ yield in mainstream smoke, we can conclude that the pore volume with pore size range of $0.1-8.0 \mu \mathrm{m}$ mainly contributed to the decrease of CO yield in mainstream smoke. 
Table 4. Pore volume of the cigarette papers in the pore size range of $0.1-200 \mu \mathrm{m}$ and $\mathrm{CO}$ yield in mainstream smoke.

\begin{tabular}{l|c|c|c|c|c}
\hline Sample & $\begin{array}{c}\text { Pore volume of } \\
0.1-8.0 \mu \mathrm{m} \\
\left(\mathrm{cm}^{3} \mathrm{~g}^{-1}\right)\end{array}$ & $\begin{array}{c}\text { Pore volume of } \\
8.0-50 \mu \mathrm{m} \\
\left(\mathrm{cm}^{3} \mathrm{~g}^{-1}\right)\end{array}$ & $\begin{array}{c}\text { Pore volume of } \\
50-200 \mu \mathrm{m} \\
\left(\mathrm{cm}^{3} \mathrm{~g}^{-1}\right)\end{array}$ & $\begin{array}{c}\text { Total pore volume } \\
\left(\mathrm{cm}^{3} \mathrm{~g}^{-1}\right)\end{array}$ & $\begin{array}{c}\text { CO yield in } \\
\text { mainstream smoke } \\
\left(\mathrm{mg} \mathrm{cig}^{-1}\right)\end{array}$ \\
\hline P1 & 0.472 & 0.482 & 0.291 & 1.245 & 12.20 \\
P1 - heated & 0.757 & 0.438 & 0.479 & 1.674 & 10.87 \\
P2 & 0.470 & 0.491 & 0.313 & 1.274 & 1.803 \\
P2 - heated & 0.818 & 0.440 & 0.545 & 1.253 & 10.80 \\
P3 & 0.432 & 0.509 & 0.312 & 1.857 & \\
P3 - heated & 0.782 & 0.431 & 0.644 & \\
\hline
\end{tabular}

Table 5. CO yield in sidestream smoke and mainstream smoke.

\begin{tabular}{l|cc}
\hline Sample & $\begin{array}{c}\text { CO yield in sidestream } \\
\text { smoke }\left(\mathrm{mg} \mathrm{cig}^{-1}\right)\end{array}$ & $\begin{array}{c}\text { CO yield in mainstream } \\
\text { smoke }\left(\mathrm{mg} \mathrm{cig}^{-1}\right)\end{array}$ \\
\hline C1 & 31.5 & 12.20 \\
C2 & 32.3 & 10.87 \\
C3 & 32.3 & 10.80 \\
\hline
\end{tabular}



Figure 5. Different areas of cigarette paper after burning: (1) preheated area, (2) incompletely pyrolyzed area, and (3) completely pyrolyzed area.

\section{Possible cause of decreased CO yield}

$\mathrm{CO}$ yield in mainstream smoke can be decreased by a combined action of $\mathrm{CO}$ diffusion and air dilution (13-16). An increase in the number of micropores of a cigarette paper produced in situ during cigarette burning facilitates CO diffusion from the mainstream to sidestream smoke. In this study, we found that the number of micropores and pore volume in a cigarette paper after heating were significantly increased, and the $\mathrm{CO}$ yield of cigarettes $\mathrm{C} 2$ and $\mathrm{C} 3$ in mainstream smoke was decreased by $\sim 10 \%$ compared with that of the control cigarette $\mathrm{C} 1$. Therefore, we speculated that the increase in the number of micropores in the samples $\mathrm{C} 2$ and $\mathrm{C} 3$ after heating, near the char line of the cigarette paper, caused the increase in $\mathrm{CO}$ diffusion. Thus, to check this assumption we measured the $\mathrm{CO}$ yield in sidestream smoke for the three cigarettes. As shown in Table 5, the $\mathrm{CO}$ yield in mainstream smoke of the cigarettes $\mathrm{C} 2$ and $\mathrm{C} 3$ was decreased by 1.33 and $1.40 \mathrm{mg} \mathrm{cig}^{-1}$ compared with that of $\mathrm{C} 1$. However, the $\mathrm{CO}$ yield in sidestream smoke of cigarettes $\mathrm{C} 2$ and $\mathrm{C} 3$ was increased by $\sim 0.8 \mathrm{mg} \mathrm{cig}^{-1}$. If the increased amount of $\mathrm{CO}$ in sidestream smoke originates from the diffusion of $\mathrm{CO}$ from the mainstream smoke, then $\sim 60 \%$ of the $\mathrm{CO}$ yield reduction of the cigarettes of $\mathrm{C} 2$ and $\mathrm{C} 3$ could be attributed to the $\mathrm{CO}$ diffusion from mainstream smoke to sidestream smoke during the static burning process. The diffusion effect is then the main cause of the decrease of the $\mathrm{CO}$ yield in mainstream smoke. Table 2 shows that "tar" contents in mainstream smoke of the cigarettes of $\mathrm{C} 2$ and $\mathrm{C} 3$ also decrease by 0.58 and $0.63 \mathrm{mg} \mathrm{cig}^{-1}$, respectively, compared with that of $\mathrm{C} 1$. "Tar" in mainstream smoke hardly diffuses into the sidestream smoke through the micropores near the char line. Therefore the reduction in the amount of "tar" can be attributed to the effect of air dilution caused by the increase in permeability of the cigarette paper near the char line during the puffing process. Given that air dilution shows no selectivity with respect to components in mainstream smoke, $\sim 40 \%$ of the CO yield $\left(\sim 0.6 \mathrm{mg} \mathrm{cig}^{-1}\right)$ in mainstream smoke is reduced by air dilution during the puffing process.

The diffusivity, permeability, and number of micropores of the heated cigarette papers P2 and P3 increased. Accordingly, the $\mathrm{CO}$ yield in mainstream smoke of the corresponding cigarettes was reduced. To confirm the change in the pore structure of the cigarette papers during the burning process, we used SEM to obtain images at the incompletely and completely pyrolyzed areas after the cigarettes were burned. The total and mean pore area, porosity and equivalent pore diameter in the cigarette paper were calculated using equations [1] to [4].

As shown in Figure 5, the cigarette paper was divided into three parts: the preheated area (white and light yellow), the incompletely pyrolyzed area (yellow and slightly black), and the completely pyrolyzed area (gray).

The morphology of the incompletely pyrolyzed area in the cigarette paper after the burning process is shown in Figure 6. A high number of micropores were produced in the incompletely pyrolyzed area ( $2 \mathrm{~mm}$ from the char line). The pore size distributions of the incompletely pyrolyzed areas of P1 and P2 were analyzed by equations [1] to [4], and the results are shown in Table 6 . In the testing area of $76.42 \mu \mathrm{m} \times 51.79 \mu \mathrm{m}, 1837$ pores with different pore sizes 


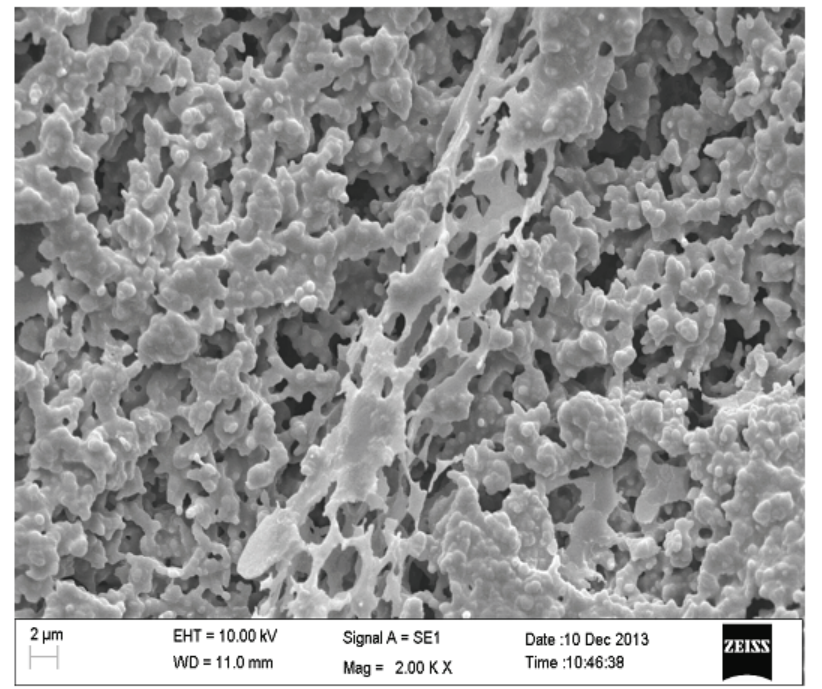

(a)

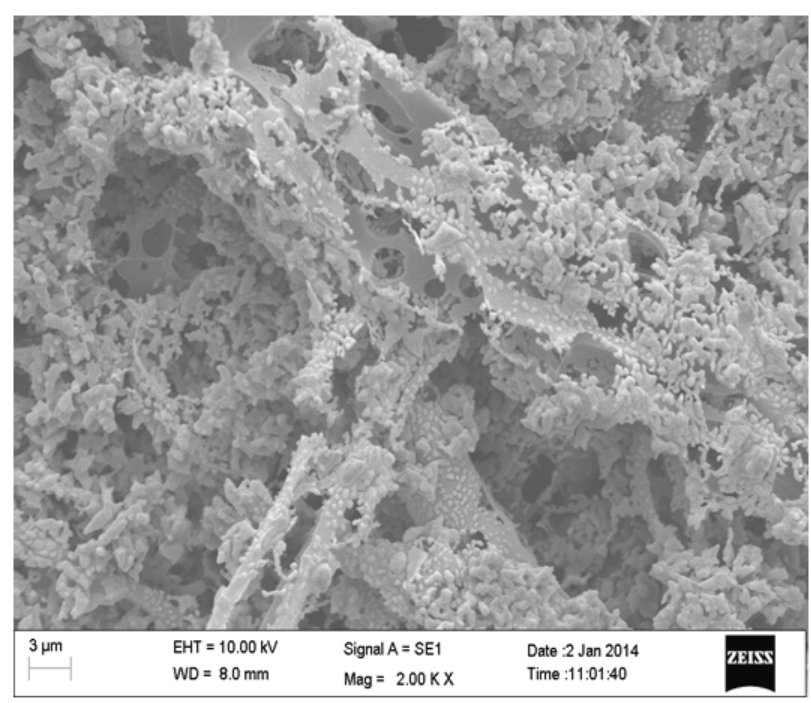

(b)

Figure 6. SEM images of the incompletely pyrolyzed areas of the cigarette papers (a) P1 and (b) P2.

Table 6. Pore structure parameters of the incompletely pyrolyzed areas.

\begin{tabular}{l|c|c|c|c|c}
\hline Sample & $n$ & $A\left(\mu \mathrm{m}^{2}\right)$ & $\bar{A}\left(\mu \mathrm{m}^{2}\right)$ & $D(\mu \mathrm{m})$ & $\rho_{/}(\%)$ \\
\hline P1 & 1837 & 1727.54 & 0.948 & 1.096 & 43.68 \\
P2 & 2489 & 1405.92 & 0.567 & 0.848 & 35.56 \\
\hline
\end{tabular}

were found in paper $\mathrm{P} 1$, and the equivalent diameter for paper P1 is $1.096 \mu \mathrm{m}$. However, 2489 pores with different pore sizes are found in the sample of $\mathrm{P} 2$, and the equivalent diameter of P2 is $0.848 \mu \mathrm{m}$. The results indicate that in paper $\mathrm{P} 2$ more micropores are present than in paper P1. In addition, the mean pore diameter and porosity are lower in the incompletely pyrolyzed area. Based on the pore structure and the CO yields as shown in Table 2, it can be con- cluded that the increased number of micropores near the char line helps to reduce the $\mathrm{CO}$ yield in mainstream smoke.

The morphology of the completely pyrolyzed area in the cigarette paper after the burning process is shown in Figure 7. The paper $\mathrm{P} 2$ has a higher number of smaller micropores than paper $\mathrm{P} 1$ in the completely pyrolyzed area of the cigarette paper. Results of the pore size distribution in the completely pyrolyzed area are summarized in Table 7. In the testing area of $227.78 \mu \mathrm{m} \times 153.33 \mu \mathrm{m}$, 4148 pores with different pore sizes are found in P2, and the equivalent diameter is $1.022 \mu \mathrm{m}$. However, only 3585 pores were observed in the testing area of $\mathrm{P} 1$, and the equivalent diameter of $\mathrm{P} 1$ is $1.128 \mu \mathrm{m}$. The results indicate that paper $\mathrm{P} 2$ can form more micropores with smaller total pore area and pore diameter than paper P1 during cigarette burning. The pore structure parameters in Tables 6 and 7,

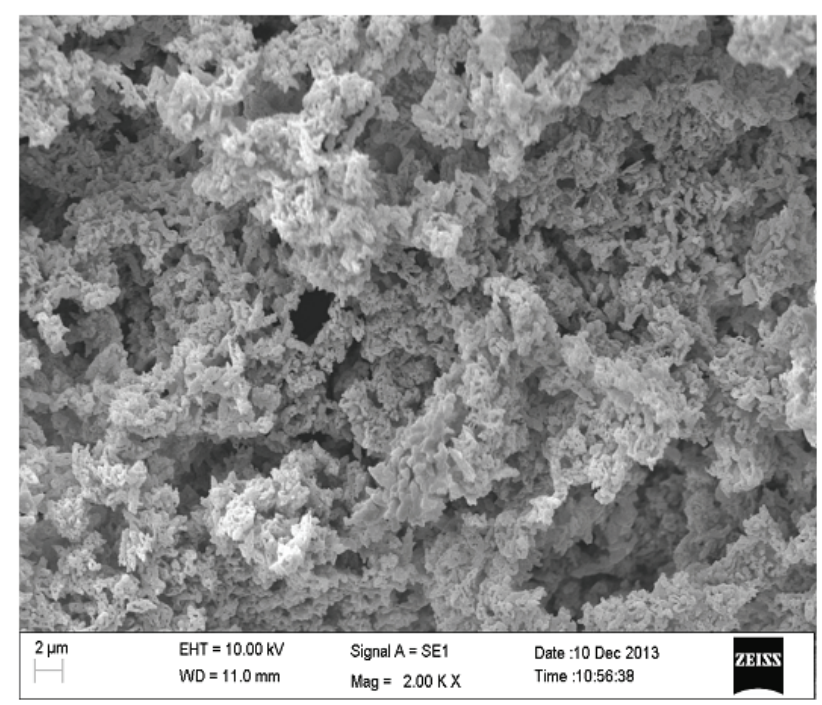

(a)

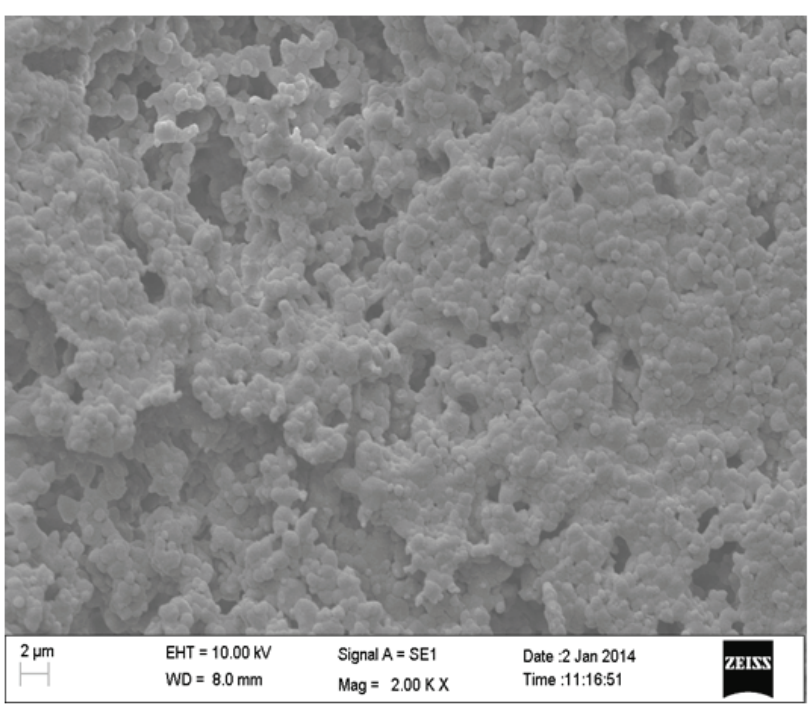

(b)

Figure 7. SEM images of the completely pyrolyzed areas of the cigarette paper (a) P1 and (b) P2. 
Table 7. Pore structure parameters of the completely pyrolyzed areas.

\begin{tabular}{l|c|c|c|c|c}
\hline Sample & $n$ & $A\left(\mu \mathrm{m}^{2}\right)$ & $\bar{A}\left(\mu \mathrm{m}^{2}\right)$ & $D(\mu \mathrm{m})$ & $\rho_{/}(\%)$ \\
\hline P1 & 3585 & 3582.37 & 1.000 & 1.128 & 10.22 \\
P2 & 4148 & 3398.32 & 0.819 & 1.022 & 9.73 \\
\hline
\end{tabular}

as well as the diffusion data in Table 3, show that more pores and smaller pore size in burned cigarette paper are favorable for reducing the $\mathrm{CO}$ yield in mainstream smoke. These results also provide an explanation for the lower $\mathrm{CO}$ yield of $\mathrm{C} 2$ in its mainstream smoke than of $\mathrm{C} 1$.

\section{CONCLUSIONS}

In conclusion, the pore structure of cigarette paper affects the $\mathrm{CO}$ yield in mainstream smoke during the cigarette burning process. The $\mathrm{CO}$ yield in mainstream smoke decreases when the volume of pores in the cigarette paper increases in the pore size range of $0.1-8.0 \mu \mathrm{m}$. Furthermore, a high number of micropores near the char line and near the area of the burning cone are also favorable for reducing the $\mathrm{CO}$ yield in mainstream smoke. The combined action of $\mathrm{CO}$ diffusion and air dilution during the cigarette burning process results in $\sim 10 \%$ decrease in $\mathrm{CO}$ yield in mainstream smoke by using the designed cigarette paper.

\section{ACKNOWLEDGEMENTS}

The project was financially supported by China National Tobacco Corp. and China Tobacco Hunan Industrial Co., Ltd. The authors gratefully acknowledge the support from Minfeng Special Paper Co., Ltd., PR China, by providing cigarette paper samples for testing.

\section{REFERENCES}

1. Wei, Y.L., J.H. Xu, Z. Liao, Q. Hu, and B. Li: Effects of Cigarette Materials on Ventilation Rate and Filtration Efficiency of Cigarette; Chin. Tob. Sci. Tech. 11 (2008) 9-13.

2. Hu, Q., B. Gu, J. Ma, B. Fang, and L.J. Peng: Influence of Natural Permeability of Cigarette Paper on Physical Properties and Smoke Delivery of Cigarette; Chin. Tob. Sci. Tech. 8 (2002) 7-10.

3. Drake, D.G., D.S. Riley, R.R. Baker, and K.D. Kilburn: On a Cell to Measure Diffusion Coefficients of Gases Through Cigarette Paper; Int. J. Heat Mass Transfer 23 (1980) 127-134.

4. Verdolotti, L., A. Salerno, R. Lamanna, A. Nunziata, P. Netti, and S. Iannace: A Novel Hybrid PU-Alumina Flexible Foam with Superior Hydrophilicity and Adsorption of Carcinogenic Compounds from Tobacco Smoke; Microporous Mesoporous Mater. 151 (2012) 79-87.
5. Li, D.L., Y.T. Wang, J. Fan, X.G. Wang, and Y.Y. Xia: Experiments on Application of Palygorskite Adsorbent Into Cigarette Filter; Chin. Tob. Sci. Tech. 4 (2003) 6-8.

6. LV, G.H., C. Nie, M.Y. Zhao, J.F. Liu, and Y. Ding: Studies on the Removal of Carbon Monoxide in Cigarette Smoke by Using Dual-Filters Contained Nano-Catalyst Materials; Acta Tabacaria Sinica 9 (2003) 18-26.

7. Yong, G.P., Z.X. Jin, H.W. Tong, X.Y. Yan, G.S. Li, and S.M. Liu: Selective Reduction of Bulky Polycyclic Aromatic Hydrocarbons From Mainstream Smoke of Cigarettes by Mesoporous Materials; Microporous Mesoporous Mater. 91 (2006) 238-243.

8. Li, P., D.E. Miser, S. Rabiei, R.T. Yadav, and M.R. Hajaligol: The Removal of Carbon Monoxide by Iron Oxide Nanoparticles; Appl. Catal. B: Environ. 43 (2003) 151-162.

9. Zhu, H.Q., Z.F. Qin, W.J. Shan, W.J. Shen, and J.G. Wang: Low-Temperature Oxidation of $\mathrm{CO}$ Over $\mathrm{Pd} / \mathrm{CeO}_{2}-\mathrm{TiO}_{2}$ Catalysts With Different Pretreatments; J. Catal. 233 (2005) 41-50.

10. Guo, J.Z., S.J. Zheng, Q.P. Yan, X.B. Zhang, and W.L. Sun: Effects of Combustion Improver in Cigarette Paper on Deliveries of Seven Harmful Components in Mainstream Cigarette smoke; Chin. Tob. Sci. Tech. 7 (2012) 43-45.

11. Hampl, V. Jr: Smoking Article with Reduced Carbon Monoxide Delivery; US Patent 6823872 B2, November 30, 2004. Available at http://www.google.com.au/ patents/US6823872 (accessed June 2015).

12. Fritzsching, T.: Covering Material for Smoking Products Having Improved Carbon Monoxide Reducing Properties; US Patent 20090044819, February 19, 2009. Available at http://www.google.com.na/patents/ WO2006042817A3?cl=en (accessed June 2015).

13. Waltz, V.P. and M. Häusermann: Betrachtungen über die Veränderung des Tabakrauches in der Zigarette; Beitr. Tabakforsch. 3 (1965) 169-191.

14. Muramatsu, M., T. Mikami, N. Nito, and H. Tomita: A Model on the Diffusion and the Dilution of Low Molecular Weight Gaseous Components Through Cigarette Paper During Smoking; Beitr. Tabakforsch. Int. 9 (1977) 141-146.

15. Rostami, A.A. and M.R. Hajaligol: Modeling the Diffusion of Carbon Monoxide and Other Gases from the Paper Wrapper of a Cigarette During Puffing; J. Anal. Appl. Pyrolysis 66 (2003) 263-280.

16. Eitzinger, B.: Permeability and Diffusivity of Cigarette Paper During its Thermal Decomposition; $61^{\text {st }}$ TSRC, Abstract 65, 2007, Charlotte, NC, USA.

17. Zhao, D.Q., Y. Dai, K.F. Chen, Y.F. Sun, F. Yang, and K.Y. Chen: Effect of Potassium Inorganic and Organic Salts on the Pyrolysis Kinetics of Cigarette Paper; J. Anal. Appl. Pyrolysis 102 (2013) 114-123.

18. Zhou, S., C. Wang, Y. Xu, and Y. Hu: The Pyrolysis of Cigarette Paper Under the Conditions That Simulate Cigarette Smouldering and Puffing; J. Therm. Anal. Calorim. 104 (2011) 1097-1106. 
Corresponding author:

Yin Donghong, Ph.D

Research and Development Center of China Tobacco Hunan Co., Ltd.

Changsha, Hunan

China

E-mail:yindh1127@hngytobacco.com andyindh@hunnu.edu.cn 